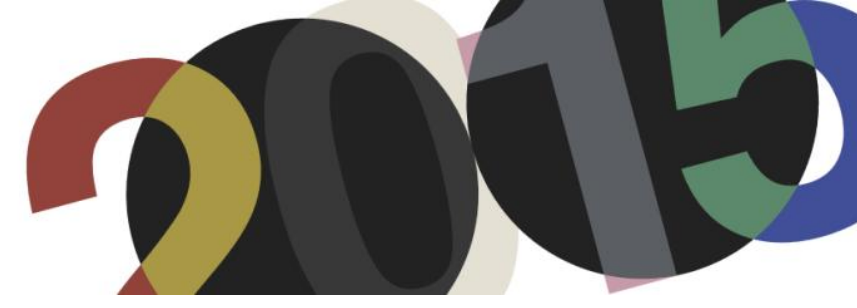

DOI: http://dx.doi.org/10.4995/LC2015.2015.712

\title{
From Impact to Legacy: Interpreting Critical Writing on Le Corbusier from the 1920s to the Present
}

\author{
G. Livesey*, A. Moulis ** \\ * Faculty of Environmental Design, University of Calgary \\ ** School of Architecture, The University of Queensland
}

\begin{abstract}
As a major figure of international modernism, Le Corbusier's work has been subject to extensive critique and review both during his lifetime and since, to the extent that he has become the world's most studied 20th century architect. While numerous attempts have been made to assess Le Corbusier's works and ideas in their meaning and influence, little attention has been given to understanding the phenomena of critical writing and research that continues to surround the architect. Drawing upon research by the authors in preparing a 4-volume anthology of writings on Le Corbusier's work for a major British publisher in 2016, the paper will trace critical reaction to the architect's practice through a survey investigation of research and writing produced mainly in English from the 1920s to the present. The paper will give a chronological account of the issues, ideas and approaches that have emerged in critical writings on Le Corbusier and his architecture, reporting on the historiographic questions that have presented themselves in undertaking such a large-scale survey work. Reviewing the work of well-known critics the survey has also sought out lesser-known voices whose presence reflects Le Corbusier's impact around the world, providing new interpretations through fresh perspectives on his work.
\end{abstract}

Keywords: Architectural criticism; Architectural historiography; 20th century architecture, Le Corbusier.

\section{Introduction}

As a major figure of international modernism, Le Corbusier's work has been subject to extensive critique and review both during his lifetime and since, to the extent that he has become the world's most studied $20^{\text {th }}$ century architect. From early discussion of his seminal treatise Towards a New Architecture in Architectural Review, to large-scale exhibitions, such as Le Corbusier: An Atlas of Modern Landscapes held at the Museum of Modern Art, New York, in 2013, the architect's work has continued to assume a relevance and interest well beyond that accorded to the work of his contemporaries, confirming his considerable influence. While numerous attempts have been made to assess Le Corbusier works and ideas in their meaning and influence, little attention has been given to understanding the phenomena of critical writing and research that continues to surround the architect.

Drawing upon research by the authors in preparing a 4-volume anthology of writings on Le Corbusier's work for a major British publisher in 2016, the paper will briefly trace critical reaction to the architect's practice through a survey investigation of research and writing produced from the 1920s to the present. The survey, which will be presented roughly chronologically, has involved examining a large bibliography of material in English as well as the consideration of material in other languages made available in translation. In the paper the issue of how Le Corbusier's self-creation of an oeuvre through his writings and projects intersected with the responses of his critics will be discussed. Also described is the role key critics played in enhancing the architect's oeuvre, setting out its received interpretation in accord with Le Corbusier's self-construction as an avant-garde architect - a construction that those critics who opposed his work would also be drawn into. From the architect's death in 
1965, Le Corbusier's work continued to have an impact as its precedents and lessons became the subject of history.

In conclusion, the paper reports on the historiographic questions that have emerged from the large-scale survey work that spans from the 1920s to the present. Reviewing the work of well-known critics the survey has also sought out lesser-known voices whose presence reflects Le Corbusier's impact around the world, providing new interpretations through fresh perspectives on his work. Despite a wealth of intensive research on the architect's life and work there are aspects of the his practice that the survey of writings reveals as little researched, suggesting that new avenues for interpretation of Le Corbusier's work remain.

\section{1920-1940}

Every direct Le Corbusier first emerged as a significant figure in the world of architecture in the 1920s with the publication of his early books and projects. Crucial to his reception in the English speaking world was the publication of two of Le Corbusier's early texts translated into English by Frederick Etchells (Towards a New Architecture published in 1927 and The City of To-morrow in 1929). Throughout his career most of Le Corbusier's many publications would be translated into English, often many years after their original publication in French, these would form an essential aspect to the dissemination, reception, and interpretation of his ideas.

The initial reception to his work in the British architectural press was often sceptical and even hostile. ${ }^{1}$ The history of Le Corbusier's reception in Britain has been well documented by Adrian Forty, who argues that it was not until after the Second Word War that his reputation became more secure, only to be challenged by the strong critique of post-war urban renewal that emerged in the 1960 s. $^{2}$ Further, the recent publication of Le Corbusier and Britain: An Anthology, edited by Irena Murray and Julian Osley provides a well-considered over-view of Le Corbusier's impact in Britain. ${ }^{3}$ However, there were those British critics who wrote sympathetically and knowingly of Le Corbusier's work in the 1920s and 1930s, including Gordon H.G. Holt, ${ }^{4}$ Harold Tomlinson, ${ }^{5}$ Howard Robertson and F.R. Yerbury, ${ }^{6}$ Frederick Etchells, ${ }^{7}$ and Herbert Read. ${ }^{8}$

Also vitally important to Le Corbusier's burgeoning international reputation was the 1932 exhibition "The International Style" exhibition curated by Henry-Russell Hitchcock and Philip Johnson at the Museum of Modern Art in New York where his work was prominently featured. This was followed up by a small solo travelling exhibition (and catalogue) prepared in 1935 and first shown at MoMA and organized by Philip

\footnotetext{
${ }^{1}$ See Alan Powers, "Introduction," in Irena Murray and Julian Osley, eds., Le Corbusier and Britain: An Anthology (Abingdon: Routledge, 2009), pp. 1-11.

2 See Adrian Forty, "Le Corbusier's British Reputation," in Michael Raeburn and Victoria Wilson, eds., Le Corbusier: Architect of the Century (London: Arts Council of Great Britain, 1987), pp. 35-41.

${ }^{3}$ See Murray and Osley, eds., Le Corbusier and Britain.

${ }^{4}$ See Gordon H.G. Holt, "The Merit of Le Corbusier," Architectural Review (Vol. 63,1928), p. 56.

${ }^{5}$ See Harold Tomlinson, “Towards a New Architecture,” Architects' Journal, 127, (Sept. 21, 1927), pp. 378-379.

${ }^{6}$ See Howard Robertson and F.R. Yerbury, Examples of French Architecture (New York: Charles Scribner's Sons, 1928).

${ }^{7}$ See Frederick Etchells, "Le Corbusier: A Pioneer of Modern European Architecture," The Studio, 96, (Sept. 1928), pp. 156163.

${ }^{8}$ See Herbert Read, “The City of To-morrow," The Listener, (Feb. 18, 1931), pp. 272-273.
} 
Goodwin, Henry-Russell Hitchcock, Philip Johnson, Alfred H. Barr, Jr., George Howe, and Joseph Hudnut. ${ }^{9}$ Marges Bacon has extensively examined Le Corbusier's impact on America following his first visit in 1935 . $^{10}$ As Bacon notes in her "Introduction" the relationship between Le Corbusier and America could be characterised as a "transatlantic exchange" in the way it functioned. ${ }^{11}$ She also provides a list of American critics who responded to Le Corbusier's emerging reputation, including Hitchcock, Johnson, Hudnut, Howe, Lewis Mumford, Catherine Bauer, and others. ${ }^{12}$ Le Corbusier's complex approach to America resulted in his book When the Cathedrals Were White: A Journey to the Country of Timid People published in English in 1947 (originally published in French in 1937).

\section{1940-1960}

The British journal Architectural Review has, since the 1920s, been a consistently important vehicle for Le Corbusier criticism and historical scholarship, publishing many articles by authors such as John Summerson, Colin Rowe, Reyner Banham, James Stirling, and Kenneth Frampton. This would include essays such as Rowe's "The Mathematics of the Ideal Villa"13 published in 1947 which has stood up as one of the most referred to early interpretations of Le Corbusier's work. In the same year and journal Lionel Brett's essay "The Space Machine: an Evaluation of the Recent Work of Le Corbusier" was also published, in which he noted that Le Corbusier's descriptions of his own work leaves the critic "more or less bludgeoned into silence." "14

An early attempt to provide a more general critical assessment of Le Corbusier's architecture during the period 1918-1947 is found in Stamo Papadaki's edited book entitled Le Corbusier, Architect, Painter, Writer published in $1948,{ }^{15}$ including contributions by Fernand Leger, José Luis Sert, and Sigfried Gideon. Reviewing it in The Art Bulletin Henry-Russell Hitchcock notes that the essays are very short, and writes that, "Doubtless the time has not yet come for a really authoritative and objective study of Le Corbusier's work."16

John Summerson's "Architecture, Painting and Le Corbusier"17 published in 1949 was the culmination of Summerson's early efforts to interpret Le Corbusier, being mainly concerned to explain the architect's formal and aesthetic language spanning his art and architectural practice in relation to the revolution in visual understanding brought about by modern painting.

In the 1950s emerged the British architectural theorist Reyner Banham, who began writing architectural criticism for the Architectural Review. Banham used Le Corbusier's Unité d'Habitation, Marseilles, to announce

\footnotetext{
${ }^{9}$ See Marges Bacon, Le Corbusier in America: Travels in the Land of the Timid (Cambridge, Mass.: MIT Press, 2001), pp. 40-47.

${ }^{10}$ Ibid., pp. 237-311.

${ }^{11}$ Ibid., pp. xiii-xvii.

${ }^{12}$ Ibid., p. xvii.

${ }^{13}$ Colin Rowe, “The Mathematics of the Ideal Villa," Architectural Review, 101, (March 1947), pp. 101-104. See also Daniel Sherer, "Le Corbusier's Discovery of Palladio in 1922 and the Modernist Transformation of the Classical Code," Perspecta, Vol. 35, (2004), pp. 20-39; and, Jeffrey Hildner,"Remembering the Mathematics of the Ideal Villa," Journal Of Architectural Education, Vol. 53, No. 3, (Feb. 1999), pp. 143-162.

${ }^{14}$ See Lionel Brett, "The Space Machine: an Evaluation of the Recent Work of Le Corbusier," Architectural Review, (November 1947), pp. 147-150.

${ }^{15}$ Stamo Papadaki, ed., Le Corbusier, Architect, Painter, Writer (New York: Macmillan, 1948).

${ }^{16}$ Henry-Russell Hitchcock, The Art Bulletin, Vol. 32, Issue 1, (1950), p. 87.

17 See John Summerson, "Architecture, Painting and Le Corbusier," in Heavenly Mansions and Other Essays on Architecture, (London: Cresset Press, 1949), pp. 177-194.
} 
Brutalism, a post-war 'movement' signalling a significant break with pre-war modernism, mainly through the critical re-evaluation of concrete as an aesthetic and expressive material. Following Summerson, Banham also entered the debate on the role of art in Le Corbusier's work in his review of an exhibition at the Institute of Contemporary Art, London, of 1953, seeing the architect's painting and sculpture as central to developments in his formal architectural language. ${ }^{18}$

The architect James Stirling's nuanced view of Le Corbusier's late works perhaps best epitomised that of fellow post-war architects - a sense of shock and puzzlement at the architect's turn to rough sculptural forms (dramatically illustrated in Le Corbusier's Chapel at Ronchamp) followed later by qualified admiration for this newfound expressive language. In his article, "Garches to Jaoul: Le Corbusier as Domestic Architect in 1927 and 1953" (1955), Stirling comments on the roughness of the building of the Maisons Jaoul, its contrast to the fineness of Paris, while Garches stands for his pre-war machine aesthetic representing for Stirling " a continuous reminder of the quality to which all architecture must aspire if modern architecture is to retain its vitality." 19 Stirling's 1956 review of Le Corbusier's Chapel at Ronchamp for Architectural Review, ${ }^{20}$ highlighted "the crisis of rationalism" noting a move in Europe towards a humanist modernism (aligned to concepts in art and culture) which was opposed to the technologically driven modernism taking hold in the United States. However, what appeared as a critical rejection by Stirling of Le Corbusier's post-war move to an expressive humanist architecture would, subsequently, turn into a more appreciative reading of this work, particularly Ronchamp. In a 1960 article for the Yale journal Perspecta, entitled “"The Functional Tradition' and Expression”, Stirling describes an unselfconscious or "vernacular" method of architectural designing embodying a "common sense" approach to architecture, which he appreciates as a valuable lesson of the so-called humanist approach that Le Corbusier took to his post-war work. ${ }^{21}$ Stirling's observation of Le Corbusier's turn in the 1930s to a concept of vernacular thinking was not made in isolation. This idea has featured heavily in the critical accounts of the architect's work from the 1960s and up to more recent scholarship by Francesco Passanti. ${ }^{22}$

Meanwhile in the United States the American magazine Architectural Forum (1941-1974) regularly published news and reviews of Le Corbusier's work. Other US journals including Architectural Record, Pencil Points/Progressive Architecture, and American Institute of Architects Journal would also consistently publish critical reviews of Le Corbusier's projects. Of note is John Entenza's magazine Arts \& Architecture which, during its history (1938-1967), participated actively in the Le Corbusier discourse. Also of interest is the phenomenon of important American art journals engaging in critical Le Corbusier scholarship, these included Art Digest, Art News, Art in America, Arts Magazine, Art Bulletin, and Art Forum which published texts by authors such as Ada Louis Huxtable, ${ }^{23}$ Sibyl Moholy-Nagy, ${ }^{24}$ and Rosalind Kraus. ${ }^{25}$

In the 1950s there emerged a strong movement to attack Le Corbusier's concepts, particularly those dealing with the city. This manifested itself in the Team 10 movement, but also with proponents of the Garden City, such as

\footnotetext{
${ }^{18}$ Reyner Banham, “The New Brutalism,” Architectural review, 118 (Dec 1955), pp. 354-361.

${ }^{19}$ See James Stirling, "Garches and Jaoul: Le Corbusier as Domestic Architect in 1927 and 1953," Architectural Review (September 1955), pp. 145-151.

${ }^{20}$ See James Stirling, "Ronchamp and the Crisis of Rationalism,” Architectural Review, (March 1956), pp. 155-61.

${ }^{21}$ See James Stirling, “"The Functional Tradition’ and Expression,” Perspecta, 6, (1960), pp. 88-97.

${ }^{22}$ See Francesco Passanti, "The Vernacular, Modernism, and Le Corbusier," Journal of the Society of Architectural Historians, 56.4, (Dec 1997), pp. 438-451.

${ }^{23}$ Ada Louis Huxtable, "French Architecture Today," Art Digest, 28, (April 15, 1954), p. 18.

${ }^{24}$ Sibyl Moholy-Nagy, "The Achievement of Le Corbusier," Arts Magazine, 40, (November 1965), pp. 40-45.

${ }^{25}$ Rosalind Kraus, "Léger, Le Corbusier and Purism," Art Forum, 10, (April 1972), pp. 50-53.
} 
F.J. Osborn and Lewis Mumford. ${ }^{26}$ This was further augmented by the writings of Jane Jacobs, notably with the publication of her influential book The Death and Life of Great American Cities in 1961 in which she deliberately conflates the urban approach of Le Corbusier's La Ville Radieuse plan with that of the American Garden City planners, fashioning the term 'Radiant Garden City Beautiful' as a means to identify and criticize then current planning practices and the social alienation she held their work responsible for. ${ }^{27}$

During the 1940s and 1950s a number of key texts by Le Corbusier were translated into English including The Four Routes,${ }^{28}$ The Home of Man, ${ }^{29}$ The New World of Space, ${ }^{30}$ and The Modulor. ${ }^{31}$

\section{4. $1960-1980$}

A set of symposia at Columbia University in New York (held between March-May 1961) brought together important critics and architects to examine the works of Le Corbusier alongside fellow modern masters Walter Gropius, Mies van der Rohe, and Frank Lloyd Wright (with a publication released in the same year ${ }^{32}$ ). Presentations on Le Corbusier by friend and collaborator, José Luis Sert, and the Italian architect and critic, Ernesto Rogers, reflected their personal admiration of the architect. The Museum of Modern Art would continue to champion Le Corbusier during Arthur Drexler's term as the director and curator of the Department of Architecture and Design (1956-1985). The exhibition "Le Corbusier: Buildings in Europe and India" was held in 1963, and a subsequent exhibition “Le Corbusier: Architecture Drawings” was shown in 1978.

A 1963 essay by the historian and urban thinker Lewis Mumford on the Unité d'Habitation, Marseilles, revealed quite a different position on the architect, criticising his building as no more innovative, in social terms, than others of its time. ${ }^{33}$ This dichotomy of views was testament to Le Corbusier's skill as a rhetorician that, in turn, played into his critical reception. As Alan Colquhoun was later to observe of this period, "whether the commentators on his work were sympathetic or antagonistic they tended to measure themselves against the myth that [Le Corbusier] himself had created. ${ }^{34}$ At the same time Le Corbusier's work was being appropriated towards agendas not necessarily of the architect's own making - for example, Reyner Banham's books Theory and Design in the First Machine Age (1960), The New Brutalism (1966) and The Architecture of the WellTempered Environment (1969) set Le Corbusier's work in particular directions - made to serve arguments tangential to the architect's personal polemics.

\footnotetext{
${ }^{26}$ See F.J. Osborn, “Concerning Le Corbusier," Town and Country Planning, 20, (July 1952), pp. 311-316; (August 1952), pp. 359-363. See Lewis Mumford, "Yesterday's City of Tomorrow," Architectural Record, 132, (November 1962), pp. 139144.

${ }^{27}$ Jacobs, Jane. The Death and Life of Great American Cities: The Failure of Town Planning (New York: Random House, 1961), pp. 21-25.

${ }^{28}$ Le Corbusier, The Four Routes (London: Dennis Dobson, 1947).

${ }^{29}$ Le Corbusier and François de Pierrefeu, The Home of Man (London: Architectural Press, 1948).

${ }^{30}$ Le Corbusier, New World of Space (New York: Reynal and Hitchcock, 1948).

${ }^{31}$ Le Corbusier, The Modulor (London: Faber and Faber, 1954).

${ }^{32}$ Four Great Makers of Modern Architecture: Gropius, Le Corbusier, Mies van der Rohe, Wright (New York: Columbia University, 1961).

${ }^{33}$ Lewis Mumford, "The Marseille 'Folly,"” in Highway and the City (New York: Harcourt, Brace and World, 1963), pp. 5366.

${ }^{34}$ Alan Colquhoun, "The Le Corbusier Centenary," Journal of the Society of Architectural Historians, Vol. 49, No. 1 (Mar., 1990), pp. 96-105.
} 
Monographs on Le Corbusier in English began appearing in the early 1960s including Peter Blake's Le Corbusier: Architecture and Form (1960) and Françoise Choay's Le Corbusier (1960). Blake's remains the first major effort to interpret Le Corbusier's work in English, and was part of a three volume series that also examined Mies van der Rohe and Frank Lloyd Wright; Blake's text is both thoughtful and highly appreciative. Maurice Besset's Who was Le Corbusier? appeared simultaneously in French and English in 1968 as a thematically organized book with a strong visual quality. ${ }^{35}$ In the 1970s less consequential books such as Martin Pawley's Le Corbusier (1970), Robert Furneaux Jordan's Le Corbusier (1972), Charles Jenck's Le Corbusier and the Tragic View of Architecture (1973), and Stephen Gardiner's Le Corbusier (1974) were produced.

Le Corbusier's death in 1965 triggered a host of tributes by distinguished architects and critics in all major architectural journals internationally. These include Richard Neutra's in the September 1965 issue of Canadian Architect, Philip Powell and Jane Drew's personal reflections in the Architects' Journal (published the same month), Henry-Russell Hitchcock's in Progressive Architecture (October 1965), Jørn Utzon's brief eulogy in the simple publication of drawings by Le Corbusier in Architecture in Australia in December 1965, and Reyner Banham's dramatically titled "The Last Formgiver" in The Architectural Review of August 1966, in which he wryly observed that the kind of unqualified admiration enjoyed by Le Corbusier from his fellow architects meant that he continued to dominate his critics, even in death. ${ }^{36}$

In 1970 the final volume of Le Corbusier's Oeuvre Complète was published. The series of eight volumes, the first of which appeared in 1929, featured projects by the architect alongside his artworks recounted through drawing, text and image. ${ }^{37}$ Edited by Willy Besieger the tri-lingual volumes (in French, German and English) have provided a key source for architects and as well as scholars internationally, despite the fact that the first volume did not include many of the works he executed before 1920.

Le Corbusier's work was by now routinely published across the globe. The Indian architecture journal Marg published regularly on Le Corbusier's work in India from the late 1950s and into the early 1960s. Other journals with regular contributions on the architect include the South African Architectural Record, Architecture in Australia, Canadian Architect, and the Royal Architectural Institute of Canada Journal.

In Britain the journal Architectural Design (under editorship of Monica Pigeon, 1946-1975) included articles on Le Corbusier by Kenneth Frampton, Alan Colquhoun and Rem Koolhaas. In turn, Architectural Association Quarterly and AA Files have regularly featured articles on Le Corbusier since the 1960s. A 1972 account in AAQ of the architect's influence on modern architecture in South Africa was indicative of impact and worldwide reach of Le Corbusier's ideas. ${ }^{38}$ US based journals such as the Journal of Architectural Education and Perspecta have

\footnotetext{
${ }^{35}$ See Peter Serenyi's review in the Journal of the Society of Architectural Historians, Vol. 30, No. 3 (1971), pp. $255-256$.

${ }^{36}$ Richard Neutra, "Le Corbusier," Canadian Architect, 10, (September 1965), pp. 23-26; Philip Powell and Jane Drew, "Le Corbusier: Appreciations," Architects' Journal, 142, (Sept. 15, 1965), pp. 1592-1593; Henry Russell Hitchcock Jr., "Le Corbusier: A Preliminary Assessment, Estimates of the Man and His Work by Architects, Critics, and Historians Who Knew Him," Progressive Architecture, 46, (October 1965), pp. 232-237; Jørn Utzon, "Le Corbusier," Architecture in Australia, 54.4, (December 1965), pp. 100-101; Reyner Banham, "Le Corbusier: The Last Formgiver," Architectural Review, 140, (August 1966), pp. 86, 97-108.

${ }^{37}$ Le Corbusier, Oeuvre Complète Vols 1-8, London: Thames \& Hudson, 1970.

${ }^{38}$ See Gilbert Herbert, "Le Corbusier and the Origins of Modern Architecture in South Africa," AAQ : Architectural Association Quarterly, 4, no. 1, (01, 1972), pp. 16- 30.
} 
also contributed regularly to the Le Corbusier debates; the $J S A H$, in particular, continues to be a vital vehicle for Le Corbusier scholarship.

One of the earliest scholarly dissertations on Le Corbusier was by the Hungarian-born American, Peter Serenyi. His essays entitled "Le Corbusier's Changing Attitude Toward Form" (1965) published in the Journal of the Society of Architectural Historians and "Le Corbusier, Fourier, and the Monastery of Ema" (1967) published in The Art Bulletin were important early works of scholarship. ${ }^{39}$ His edited collection Le Corbusier in Perspective (1975) brought together essays that encapsulated Le Corbusier studies until that time.

Norma Evenson, who taught at UC Berkeley from 1963 to 1993, produced other significant early scholarship, publishing a seminal account of Le Corbusier's urban project at Chandigarh in 1966, based on several personal visits she had taken to the city. ${ }^{40}$ Urban planner Philippe Boudon's sociological perspective on Le Corbusier's housing complex at Pessac (first published in French in 1969) remains a classic critique of the architect's work. ${ }^{41}$ The establishment of the Fondation Le Corbusier in 1968 and the publication in the same year of Stanislaus von Moos' Le Corbusier: Elemente einer Synthese (English edition 1979) contributed to a significant new context for constructing Le Corbusier's legacy. As Tim Benton has noted, an important aspect of von Moos' first attempt to overview the architect's career was to find a place for his art, providing a means to situate it in an art historical context as never before. ${ }^{42}$ Reviewing the text in 1971, Serenyi writes, "Mr. von Moos' book is the first attempt to grasp the entire work of Le Corbusier in a more comprehensive way....this book will remain an indispensable tool for the specialist and nonspecialist alike." ${ }^{43}$

By the early 1970s a host of new Le Corbusier scholars began to establish themselves, using the archives available through the Fondation. In accessing previously unseen materials interest turned to Le Corbusier's early years and his architectural formation. Scholarly research by Paul Turner and Mary Sekler, both undertaking dissertations through the Department of Fine Arts at Harvard University, dealt respectively with the architect's early education and drawings, becoming the first of a wave of studies attempting objective assessments of Le Corbusier situated in a broader social and historical context. ${ }^{44}$ Other early scholars included: Joyce Lowman on the formative influence of engineer Max DuBois on Le Corbusier; Brian Brace Taylor on the Cite de Refuge project; William J.R. Curtis and Eduard F. Sekler on the Carpenter Center; and the work of New Zealand historian and architect, Russell Walden, who edited The Open Hand: Essays on Le Corbusier for MIT Press in 1977 which included essays by several key Le Corbusier scholars who emerged during this period. ${ }^{45}$

\footnotetext{
${ }^{39}$ Peter Serenyi, "Le Corbusier's Changing Attitude Toward Form," Journal of the Society of Architectural Historians, 24 , no. 1, (March 1965), pp. 15-23, and "Le Corbusier, Fourier and the Monastery of Ema," The Art Bulletin, 49.4, (December 1967), pp. 277-286.

${ }^{40}$ Norma Evenson, Chandigarh (Berkeley, University of California Press, 1966).

${ }^{41}$ Philippe Boudon, Lived in Architecture: Le Corbusier's Pessac Revisited (Cambridge, Mass.: MIT Press, 1972).

${ }^{42}$ Tim Benton, "New Interpretations, New Evidence," in The Villas of Le Corbusier and Pierre Jeanneret, 1920-1930 (Basel: Birkhäuser, 2007), p. 213.

${ }^{43}$ See Peter Serenyi's review in the Journal of the Society of Architectural Historians, Vol. 30, No. 3 (1971), pp. 256-258.

${ }^{44}$ Paul Turner, The Education of Le Corbusier (New York: Garland Publishing, 1977) and Mary P. M. Sekler, The Early Drawings of Charles-Eduard Jeanneret (Le Corbusier) (New York: Garland Publishing, 1977).

45 Joyce Lowman, "Corb as Structural Rationalist," The Architectural Review, (October 1976), pp. 229-293; Brian Brace Taylor, Le Corbusier: La Cité de Refuge 1929/33 (Paris: Equerre, 1980); Eduard F. Sekler and William J.R, Curtis, Le Corbusier at Work: The Genesis of the Carpenter Center for the Visual Arts (MIT Press: Cambridge, Mass., 1978) and Russell Walden (ed), The Open Hand: Essays on Le Corbusier (MIT Press: Cambridge, Mass., 1977).
} 
Two important issues of Oppositions (no. 15/16 in 1979 and no. 19/20 in 1980) focussing on Le Corbusier and edited by Kenneth Frampton represented the centrality of Le Corbusier's work to the architectural theory agendas of the period. For example, Peter Eisenman's essay on the semiotics of the Domino frame, and Barry Maitland's on "The Grid" indicated the way in which Le Corbusier's work, interpreted as a formal language by both critics and architects, was instrumentalised by the new avant-gardes. Mary McLeod's critique of the work in Algiers, Jean-Louis Cohen's study of Le Corbusier's travels to the Soviet Union, and Kenneth Frampton's on the magazine Espirit Nouveau pointed forward to pre-occupations with broader social, political and cultural issues that would dominate the critical reception of the architect's work in the following decades.

During the 1960s and 1970s further publications by Le Corbusier appeared in English including Creation is a Patient Search, ${ }^{46}$ Le Corbusier Talks with Students from School of Architecture, ${ }^{47}$ The Radiant City, ${ }^{48}$ and The Athens Charter. ${ }^{49}$

\section{1980-2000}

In 1981-1982 the Architectural History Foundation and MIT Press published Le Corbusier's sketchbooks in four volumes. Almost in parallel, between 1982 and 1985, the 32 volumes of Le Corbusier's architectural drawings were published by Garland and edited by H. Allen Brooks (with the related publication of essays accompanying each volume). The essay topics ranged from scholarly analysis of projects or periods in the architect's career, biographical accounts by collaborators and broad surveys of his output. Tim Benton argues that prior to 1984 most material on Le Corbusier "were works of architectural analysis and appreciation," and that after this a period of "genetic" scholarship commenced. ${ }^{50}$

Closer art historical research into the Purist painting phase of Le Corbusier's career begins in 1970s and continued into the 1980s with scholarship undertaken by Kenneth E. Silver, Susan L. Ball, and Christopher Green. ${ }^{51}$ These studies looked beyond a pure examination of the formal connections between Le Corbusier's art and architecture that had dominated earlier critical accounts, seeking to contextualise his art practice within a broader cultural setting and in his working relationship with friend and collaborator Amédée Ozenfant.

Earlier work dealing with Le Corbusier's use of symbols in his art and architecture as well as drawings and poetry appears in the criticism of Richard Allen Moore (1980), which examined esoteric themes in the "Poem of

\footnotetext{
${ }^{46}$ Le Corbusier, Creation is a Patient Search (New York: Praeger, 1960).

${ }^{47}$ Le Corbusier, Le Corbusier Talks with Students form the Schools of Architecture (New York: Orion Press, 1961).

${ }^{48}$ Le Corbusier, The Radiant City: Elements of a Doctrine of Urbanism to be Used as the Basis of Our Machine-Age Civilization (New York: Orion Press, 1967).

${ }^{49}$ Le Corbusier, The Athens Charter (New York: Grossman, 1973).

${ }^{50}$ Benton, "New Interpretations, New Evidence," pp. 213-215.

${ }^{51}$ Kenneth E. Silver, Espirit de Corps: The Art of the Parisian Avant-garde and the First World War, 1914-1925 (Princeton: Princeton University Press, 1989); Susan L. Ball, Ozanfant and Purism: The Evolution of a Style, 1915-30 (UMI Research Press, 1982); and, Christopher Green "The Architect as Artist," in Michael Raeburn and Victoria Wilson, eds., Le Corbusier: Architect of the Century (London: Arts Council of Great Britain, 1987), pp. 110-130.
} 
the Right Angle" (based on his prior research and PhD dissertation at Ann Arbor) ${ }^{52}$ and Stuart Cohen and Steven Hurtt's assessment of primitive archetypes in relation to the Chapel at Ronchamp. ${ }^{53}$

William J.R. Curtis's book Le Corbusier: Ideas and Forms, published in 1986, presented a broad and readable synopsis of the architect's career highlighting the historian's search for precedents and symbolic themes in his work. Intended to synthesize scholarship undertaken in the 1970s and 1980s, Curtis draws from secondary sources including particularly the work of von Moos, Serenyi, Banham, Rowe, and Colquhoun. ${ }^{54}$

In the 1980s key Le Corbusier scholars, Colquhoun, Frampton and Jean-Louis Cohen produced important critical work. Colquhoun's writings on Le Corbusier appearing in his Essays in Architectural Criticism (1981) and Modernity and the Classical Tradition (1989) largely undertook the task of squaring Le Corbusier's modernist approach with the architectural historicism that preceded it, seeing hidden continuities, mainly in the form of inversions of past practices, in the architect's design methods. Both Frampton and Cohen, who had critical work featured in the journal Oppositions, would go on to write major synoptic accounts of Le Corbusier in the 2000s.

Celebration of the centennial of Le Corbusier's birth in 1887, include major retrospective exhibitions at the Hayward Gallery in London organized by Tim Benton, Neave Brown, Christopher Green, and Richard Francis (along with the publication of it catalogue Le Corbusier: Architect of the Century) and the Pompidou Centre in Paris, which staged Le Corbusier, 1887-1965: une encyclopedie with a catalogue edited by Jacques Lucan. Both were important events generating a host of new critical and historical research on the architect. The centennial year also saw the publication of special issues of journals devoted to Le Corbusier, which included The Architectural Review, Architecture d'aujourd'hui, Casabella, Bauwelt, Assemblage, Archt and the South American journal Projeto. Published for the first time in English in 1987 were two major works of scholarship by Tim Benton and Brian Brace Taylor. Benton's study of the villas of the 1920s, based on his detailed examination of the Le Corbusier Archives, had been originally published in French in 1984, and was later revised in 2007. ${ }^{55}$ Benton, along with the ground-breaking study of the villas and his significant contribution to the Architect of the Century exhibition and catalogue emerged as an important Le Corbusier scholar during this period. Brian Brace Taylor's landmark study of the Cité de Refuge project in Paris, first published in French in 1980, finally appeared in English during the centennial year. ${ }^{56}$

The year also featured the first English translations of two major texts by Le Corbusier, The Decorative Art of Today (translated by James Dunnett, and originally published in 1925) and Journey to the East translated by Ivan Zaknic (first published in French in 1966). The latter publication established a new wave of interest in this period of Le Corbusier's life and several scholars in the 1980s and 1990s examined Le Corbusier's early travels including Giuliano Greseli, Sibel Bozdogan, Zeynep Çelik, and Stanislaus von Moos. Subsequently, in 1991, a translation by Edith Schreiber Aujame of Le Corbusier's Precisions appeared which would complete the English

\footnotetext{
${ }^{52}$ Richard Allen Moore, Le Corbusier: Myth and Meta Architecture: The Late Period (1947-1965), (Atlanta: Georgia State University, 1977), Le Corbusier and mécanique spirtuelle, (Ann Arbor, UMI, 1979) and 'Alchemical and mythical themes in the poem of the Right Angle, 1945-65', Oppositions, no. 19/20, (Winter-Spring 1980), pp. 111-139.

${ }^{53}$ Stuart Cohen and Steven Hurtt, "The Pilgrimage Chapel at Ronchamp," Oppositions, no. 19/20, (Winter/Spring 1980), pp.142-159.

${ }^{54}$ William J.R. Curtis, Le Corbusier: Ideas and Forms (Oxford: Phaidon, 1986), pp. 8-9.

${ }^{55}$ Tim Benton, The Villas of Le Corbusier and Pierre Jeanneret, 1920-1930 (Basel: Birkhäuser, 2007).

${ }^{56}$ Brian Brace Taylor, Le Corbusier, the City of Refuge, Paris 1929/33 (Chicago: University of Chicago Press, 1987).
} 
translations of Le Corbusier's major texts; reviewing the book, Mary McLeod underscores how difficult translating Le Corbusier can be and laments the lack of a scholarly introduction to the work translated so many years after its original publication in $1930 . .^{57}$

Communities of scholars were now forming, creating debates around Le Corbusier's work through new perspectives. For example the Berlin-based architecture journal Daidalos (1981-2001) publishing in both German and English, featured several important essays by critic/historians such as Bruno Reichlin, Werner Oeschlin, Giuliano Gresleri, Peter Carl, and Jürgen Joedicke in which discussion of the architect's ideas and projects produced an opportunity to play out contemporary concerns of the discipline in a way that gave Le Corbusier's work renewed relevance.

Into the 1990s more specialist scholarship emerged bringing interdisciplinary concepts and questions to Le Corbusier's work. For example in her celebrated book Privacy and Publicity: Modern Architecture as Mass Media of 1994, Beatriz Colomina brought a distinctive agenda to the discussion of Le Corbusier's work. ${ }^{58}$ In referring to the architect's extensive archives, she examined photographs, drawings and advertising laid out in his publications as a means to foreground practices of representation that emerged with the rise of mass media in the twentieth century, arguing that media was actively displacing architecture from its traditional expression through built works.

The publication in 1997 of H. Allen Brooks' monumental work on Le Corbusier's early career entitled Le Corbusier's Formative Years: Charles-Edouard Jeanneret at La Chaux-de-Fonds, ${ }^{59}$ built on his detailed research begun in the 1970s, and established new understandings of Le Corbusier's early ideas and influences, while continuing to stand as essential scholarship.

Alan Colquhoun in his review of Le Corbusier 1987 centennial publications in the JSAH notes how the critical reception of the architect now had a more objective tone, proving that "Le Corbusier studies had evolved from the mythologies and demonologies of the 1950s. ${ }^{, 60}$ While this was certainly true it is also the case that, by the 1990s, Le Corbusier's work was being contextualised in a much broader cultural field - beyond the specifics of earlier disciplinary debates.

\section{2000-Present}

In the introduction to his 2001 book simply titled Le Corbusier Kenneth Frampton ponders the redundancy of rewriting the history of the architect's oeuvre - so amply described by historians (including himself) in the previous five decades. Yet, not surprisingly, Frampton's answer comes in acknowledging the continued emergence of finely detailed scholarship that throws ever more light on its subject - highlighting the broad scope of his production across architecture, urbanism, painting, graphic design and publishing. Reviewing Frampton's book William J.R. Curtis complains that the number of works providing a full overview of Le Corbusier's career

\footnotetext{
${ }^{57}$ Mary McLeod, "Le Corbusier: Precisions," Journal of the Society of Architectural Historians, Vol. 55, No. 1 (March 1996), p. 92.

${ }^{58}$ Beatriz Colomina, Privacy and Publicity: Modern Architecture as Mass Media (Cambridge, Mass: MIT Press, 1994).

${ }^{59}$ H. Allen Brooks, Le Corbusier's Formative Years: Charles-Edouard Jeanneret at La Chaux-de-Fonds (Chicago: University of Chicago Press, 1997).

${ }^{60}$ See Colquhoun, “The Le Corbusier Centenary," pp. 96-105.
} 
are few, and that Frampton's work follows his typical themes, is "extremely compressed," and often lacks a sympathetic description of the projects. ${ }^{61}$ Also acknowledging the range and diversity of Le Corbusier's output was a 2001 conference Le Corbusier \& the Architecture of Reinvention held at the Architectural Association, London. Convened by Mohsen Mostafavi and Charles Jencks in response to the latter's publication Le Corbusier and the Continual Revolution in Architecture (2000), the event highlighted new work of established critics alongside the work of then emerging scholars such as Hilde Heynen and Daniel Naegele.

Detailed scholarship continued to be produced and a host of books on Le Corbusier exposing very specific aspects of his career, and new interpretations, appeared. Books on photography, travels, automobiles and the machine aesthetic, including: Marges Bacon's book Le Corbusier in America: Travels in the Land of the Timid (2001); Simon Richards' Le Corbusier and the Concept of Self (2001); Alexander Tzonis's Le Corbusier: the poetics of machine and metaphor (2001); Catherine de Smet's Le Corbusier: Architect of Books (2005); Antonio Amado's Voiture Minimum: Le Corbusier and the Automobile (2011); Christine Boyer's Le Corbusier: home de lettres (2011); Arthur Rüegg's Le Corbusier: Furniture and Interiors (2012); and, Tim Benton's LC foto: Le Corbusier, Secret Photographer (2013). Large-scale synoptic works also emerged including Jean-Louis Cohen's documentary opus Le Corbusier: Le Grand (2008) and a populist biography of Le Corbusier's life by Nicholas Fox Weber also published in $2008 .^{62}$

Le Corbusier's range of material output - from architectural models and drawings to paintings and sculpture became the subject of major exhibitions including L'Esprit Nouveau: Purism in Paris, 1918-1925 (Le Corbusier, Ozenfant and Leger) held at the Los Angeles County Museum of Art in 2001, ${ }^{63}$ and Le Corbusier ou la Sythése des Arts at the Musée Rath, Geneva, in 2006, the latter attempting to highlight Le Corbusier's artistic output in its own right - separately of his architectural work. Following were large-scale touring exhibitions combining original materials with newly commissioned models and photographs: Le Corbusier: The Art of Architecture, organized by the Vitra Design Museum in collaboration with the Netherlands Architecture Institute, the Royal Institute of British Architects and the Fondation Le Corbusier in 2007, and Le Corbusier: An Atlas of Modern Landscapes curated by Jean-Louis Cohen for the Museum of Modern Art, New York, in 2013. The catalogue edited by Cohen provides a range of geographically organized short essays by mainly established scholars that also indicate possible directions for new scholarship. ${ }^{64}$

In 2007 a new English translation by John Goodman of Le Corbusier's most important text is published, with the corrected title Toward an Architecture. Featuring a lengthy introduction by Jean-Louis Cohen, the text attempts to correct the many faults found in Frederick Etchells' translation of 1927. Tim Benton praises the scholarly effort, but suggests that a certain spirit found in the Etchells version has been lost. ${ }^{65}$

Recent research of Le Corbusier has tended to seek out what might be seen as hidden aspects of the architect's career, constructing arguments about his motivations and architectural precedents that cannot be understood as a

\footnotetext{
${ }^{61}$ William J.R. Curtis, “The ever-elusive Le Corbusier - even today writers can't quite figure him out," Architectural Record, Vol. 190, No. 2, (February 2002).

${ }^{62}$ Simon Richards' and Nicholas Fox Weber's books, along with several other recent publications, have been reviewed in Tim Benton, "New Books on Le Corbusier," Journal of Design History, Vol. 22, No. 3, (2009), pp. 271-284.

${ }^{63}$ See Carol S. Eliel, L'Esprit Nouveau: Purism in Paris, 1918-1925 (Los Angeles: Los Angeles County Museum of Art, 2001).

${ }^{64}$ Jean-Louis Cohen, ed., Le Corbusier: An Atlas of Modern Landscapes (London: Thames and Hudson, 2013).

${ }^{65}$ See Tim Benton, "Le Corbusier: Toward an Architecture (1924)," Journal of Architectural Education, Vol. 62, No. 1, (September 2008), pp. 74-75.
} 
straightforward deepening of the paths of preexisting scholarship. For example, new sources of Le Corbusier's 'modernity' are discovered in unlikely places; the particular vernacular architectures of the Balkan and the Bosphorus regions as described by Adolf Max Vogt in Le Corbusier: The Noble Savage $e^{66}$ or the copying of precedents out of the work of $18^{\text {th }}$ century architect François Joseph Belanger as proposed by Jan Birkstead. ${ }^{67}$ Birkstead's research is also notable for looking beyond the vast resources of the Fondation to access materials from Le Corbusier's Swiss hometown La Chaux-de-Fonds in an attempt to construct new and previously undisclosed perspectives on the work. The journal Massilia operating between 2002 and 2013 looked at Le Corbusier's impact in South American and outside Europe, giving further definition to communities of researchers that have built around the architect's work, undertaking historical studies by which we can continue to deepen our understanding of the architect in his times. Significant work presented in Massilia included Maria Cecilia O'Byrne's essay on Le Corbusier's Mundaneum museum and the 2007 edition devoted to discussion of the Chilean architect Guillermo Jullian de la Fuente - between 1959 and 1965 one of Le Corbusier's chief collaborators and credited as co-author of the Venice Hospital project. ${ }^{68}$

Though the 1991 publication in English of Le Corbusier's Precisions stands as the last major text to be made available in translation, recent scholarship has continued to reveal significant unpublished material by the architect. For example, Le Corbusier's early manuscript "La Construction de Villes" (The construction of cities) - compiled by Christoph Schnoor and published for the first time in German in 2008 - evidences the young Le Corbusier's encounter with principles of city design during his travels in Berlin and Munich in 1910-11 and is yet to appear in English. ${ }^{69}$

\section{The historiography of criticism}

A decade-by-decade analysis of the Avery Index of Architectural Periodicals shows ever-increasing growth in the number of articles specifically addressed to Le Corbusier and his work. The only exception is the decade of the 1970s, following Le Corbusier's death in 1965, in which the number of commentaries diminished to the level they had been in the 1940s. This relative hiatus in writing on Le Corbusier marked a period of transition from direct dealing with the architect and his works to reflections on his ideas and approaches - their origins, meaning and continued relevance. However, from the 1980s to the present, growth in critical scholarship and writing on Le Corbusier became exponential once again - taking up at almost double the level it had been in the 1960s. Since 2000 there has been nearly 900 articles on Le Corbusier in architectural periodicals. This is comparable to discussion of contemporary star-architects, such as Rem Koolhaas and Zaha Hadid, who each have up to 950 articles addressed to them and their work over the same period. Beyond this comparison, if we add the large exhibitions and major book publications previously mentioned that have been produced on Le Corbusier since 2000 , it is evident that critical reflections on his work play a significant role in the disciplinary context as well as in broader public discourse of architecture.

\footnotetext{
${ }^{66}$ Adolf Max Vogt, Le Corbusier, The Noble Savage: Towards an Archeology of Modernism (Cambridge, Mass.: MIT Press, 2000).

${ }^{67}$ Jan Kenneth Birksted, "The Politics of Copying: Le Corbusier's Immaculate Conception," Oxford Art Journal, 30, 2 , (2007), pp. 305-326.

${ }^{68}$ See Maria Cecilia O’Byrne, "El museo del Mundaneum : génesis de un prototipo, “ Massilia (2004), pp.112-135 and the special issue on Guillermo Jullian de la Fuente, Massilia (2007).

${ }^{69}$ Christoph Schnoor, (ed.) La Construction des Villes: Le Corbusiers erstes stadtebauliches Traktat von 1910/11 (Berlin: Verlag, 2008).
} 
The historiography of criticism of Le Corbusier also reveals the way in which well-known historian/critics made their reputations out of their commentaries on the architect, and continued to deepen their investigation of his work - sometimes re-visiting their own earlier interpretations - Colin Rowe, Reyner Banham, Alan Colquhoun, Timothy Benton, Stanislaus von Moos, Jean-Louis Cohen, William Curtis, Mary McLeod, and Beatriz Colomina for example. Of particular note is the 2013 revised edition of Moos' Elements of a Synthesis (1968) that provides an additional survey addressed to a host of recent scholarship on Le Corbusier, reengaging themes and materials laid out by Moos in his original critical account.

By the early 1990s critics began to frame Le Corbusier's output through a range of interdisciplinary perspectives - media and gender studies, psychoanalysis and post-colonialism - situating the work in diverse contexts that answered to debates of contemporary interest in the redress of history. Concern moved away from an examination of the built work to other forms of his production - texts, drawings, photographs, notes and letters that offered new sites of investigation. Le Corbusier's work seen in relation to the social and cultural attitudes of the times provided fertile ground for commentary and discussion. Yet even though the work of his contemporaries may well have raised the very same issues and attitudes, seen in such close examination, for scholarship, it was Le Corbusier and his work that became emblematic of the means by which to negotiate and understand them - much the same as the architect's work had stood in for the modernist project up to half a century earlier.

Looking closely at material written by established historians who have examined Le Corbusier's work over several decades, it is also possible to observe how views of the architect change. While the early versions of their research capture a vitality and strength of perspective - writing that is, in most cases, well known - their later works are inevitably more nuanced and complex incorporating new research material and greater reflection. The resulting understanding of Le Corbusier as an architect and historical figure is myriad rather than singular, as Jean-Louis Cohen's attempt to capture the various personas of the architect in his 2008 Introduction to $L e$ Corbusier: Le Grand vividly illustrates. ${ }^{70}$

Le Corbusier's archives held by the Fondation Le Corbusier in Paris are indeed extensive comprising 400,000 documents and the forms of access to them has shaped possibilities of research. From its inception in 1968, the Fondation inevitably provided impetus to historical study. In the 1970s initial investigations focussed on the architect's early years, while later into the 1980s attention moved to individual projects or sets of works within a period. Since 1990 the Fondation has taken a more active role in fostering research, holding annual meetings of researchers and publishing Le Corbusier's works and writings. With the digitisation of the archive in the 1990s improved access to research materials fed growth in scholarship - making new and diverse kinds of study possible.

Compiling the history of Le Corbusier has been a worldwide endeavour. The architects many travels have produced an array of critical accounts focussed on the places he visited, lectured, worked and staged exhibitions. Despite the 'universality' of Le Corbusier's modernism it is clear that the architect's encounters with national and regional contexts constitute unique circumstances of investigation. As Alan Power notes Le Corbusier's work has often acted as a mirror to the societies with which he engaged ${ }^{71}$ and a similar kind of reception of the

\footnotetext{
${ }^{70}$ Jean-Louis Cohen, “The Man with a Hundred Faces," in his Le Corbusier Le Grand (New York: Phaidon, 2008), pp. 6-17.

${ }^{71}$ Powers, "Introduction," in Murray and Osley, eds., Le Corbusier and Britain, p.1.
} 
architect's work can be found in scholarship. The work of Indian scholars on Le Corbusier's work at Chandigarh, for example, evidences the rehearsal of issues of nationhood and identity that speak strongly to an internal audience as much as to audiences interested in the impact of the architect's work globally. Documenting contributions to this national debate are a set of publications marking various anniversaries since the conception of Chandigarh - Chandigarh: Forty Years After Le Corbusier, Celebrating Chandigarh: 50 years of the idea, Le Corbusier: Chandigarh and the Modern City - Insights into the Iconic City Sixty Years Later, and Vikramaditya Prakash's 2002 book Chandigarh's Le Corbusier: The Struggle for Modernity in Postcolonial India - indicating the way Le Corbusier's legacy continues to be shaped by renewed interpretations of his cultural encounters. ${ }^{72}$

\section{Conclusions}

The selecting of material, currently available in English, for a large anthology of writings on Le Corbusier presents many challenges. Firstly, we determined that it is important to capture a chronology of his life including important periods, developments, projects, and themes. Secondly, it is vital to include material from across the many decades of writing on his work and by key Le Corbusier scholars. Thirdly, it is also crucial to include less well-known writings that contribute to the larger discourses. Fourthly, the availability of material in translation is also a key consideration to capture the tone of distinctive of national debates around Le Corbusier's work, although we recognize that much important scholarship has not been translated into English. Fifthly, that we include at most 2-3 contributions by a single author, and limit the number of articles from a particular collection in order to produce a balanced yet diverse coverage of sources.

What also emerges from a survey as extensive as the one we are undertaking is the vastness of scholarly materials on Le Corbusier and yet the presence of gaps in the research. For example, more attention might be paid to Le Corbusier's design of individual urban projects beyond the obvious interest in Chandigarh, which continues to be object of new criticism. The role and impact of Le Corbusier's architectural collaborators might be better interpreted beyond the personal commentaries and recollections of those individuals - for example, studies of the likes of André Wogenscky, Iannis Xenakis, Maxwell Fry, Jane Drew, the art agent Heidi Weber, and others. While work has certainly begun on his collaboration with figures such as Charlotte Perriand, Guillermo Jullian de la Fuente and his cousin Pierre Jeanneret, there is certainly more research that could emerge. Le Corbusier's unbuilt projects undertaken in the last years of his career have also received limited attention, as has his work with Jean Prouvé on the post-war project for prefabricated steel housing. Finally, is it time for a new book that examines the entire career, or has that task become too monumental? ${ }^{73}$ For the fact that these omissions (and no doubt others) still exist in our understanding of one of the key architects of the $20^{\text {th }}$ century, who is also the more studied of his time, is to admit to the strong and seemingly inexhaustible fascination that remains around the figure of Le Corbusier now 50 years after his death.

\footnotetext{
${ }^{72}$ C. Gordon and K. Kilian, eds., Chandigarh: Forty Years After Le Corbusier, (Amsterdam: Architectura \& Natura, 1991); Jaspreet Takhar, ed., Celebrating Chandigarh, (Chandigarh: Chandigarh Perspective, 2001); Hasan-Uddin Kahn, ed., Le Corbusier: Chandigarh and the Modern City: Insights into the Iconic City Sixty Years Later, (Ahmedabad: Mapin Publishing, 2009); Vikramaditya Prakash, Chandigarh's Le Corbusier: The Struggle for Modernity in Postcolonial India, (Seattle: University of Washington Press, 2002).

${ }^{73}$ Beyond recent detailed scholarly accounts, Le Corbusier has also become the subject of popular biography. See Anthony Flint, Modern Man: The Life of Le Corbusier, Architect of Tomorrow (New York: New Harvest, 2014)
} 


\section{Bibliography}

Bacon, Marges. Le Corbusier in America: Travels in the Land of the Timid, Cambridge, Mass.: MIT Press, 2001.

Ball, Susan L. Ozanfant and Purism: The Evolution of a Style, 1915-30, UMI Research Press, 1982.

Banham, Reyner. “The New Brutalism,” Architectural review, Vol. 118, 1955, pp. 354-361.

Benton, Tim. The Villas of Le Corbusier and Pierre Jeanneret, 1920-1930, Basel: Birkhäuser, 2007.

Birksted, Jan Kenneth. "The Politics of Copying: Le Corbusier's Immaculate Conception," Oxford Art Journal, 30, 2007, pp. 305-326.

Boudon, Philippe. Lived in Architecture: Le Corbusier's Pessac Revisited, Cambridge, Mass.: MIT Press, 1972.

Brett, Lionel. "The Space Machine: an Evaluation of the Recent Work of Le Corbusier," Architectural Review, Vol. 102, 1947, pp. 147-150.

Brooks, H. Allen. Le Corbusier's Formative Years: Charles-Edouard Jeanneret at La Chaux-de-Fonds, Chicago: University of Chicago Press, 1997.

Cohen, Jean-Louis, ed., Le Corbusier: An Atlas of Modern Landscapes, London: Thames and Hudson, 2013.

Cohen, Jean-Louis; Benton, Tim. Le Corbusier Le Grand, New York: Phaidon, 2008.

Colomina, Beatriz. Privacy and Publicity: Modern Architecture as Mass Media, Cambridge, Mass: MIT Press, 1994.

Colquhoun, Alan. "The Le Corbusier Centenary," Journal of the Society of Architectural Historians, Vol. 49, No. 1, 1990, pp. 96-105.

Curtis, William. Le Corbusier: Ideas and Forms, Oxford: Phaidon, 1986.

Etchells, Frederick. "Le Corbusier: A Pioneer of Modern European Architecture," The Studio, No. 96, 1928, pp. 156-163.

Evenson, Norma. Chandigarh, Berkeley, University of California Press, 1966.

Gordon, C.; Kilian, K. eds., Chandigarh: Forty Years After Le Corbusier, Amsterdam: Architectura \& Natura, 1991.

Herbert, Gilbert. "Le Corbusier and the Origins of Modern Architecture in South Africa," AAQ : Architectural Association Quarterly, 4, no. 1, 1972, pp. 16- 30.

Hildner, Jeffrey. "Remembering the Mathematics of the Ideal Villa," Journal Of Architectural Education, Vol. 53, No. 3, 1999, pp. 143-162.

Holt, Gordon H.G. “The Merit of Le Corbusier,” Architectural Review, Vol. 63, 1928, p. 56.

Huxtable, Ada Louis. “French Architecture Today,” Art Digest, 28, 1954, p. 18.

Jacobs, Jane. The Death and Life of Great American Cities: The Failure of Town Planning, New York: Random House, 1961.

Kahn, Hasan-Uddin. ed., Le Corbusier: Chandigarh and the Modern City: Insights into the Iconic City Sixty Years Later, Ahmedabad: Mapin Publishing, 2009.

Kraus, Rosalind. "Léger, Le Corbusier and Purism," Art Forum, 10, 1972, pp. 50-53.

Le Corbusier, The Four Routes, London: Dennis Dobson, 1947.

Le Corbusier; de Pierrefeu, François. The Home of Man, London: Architectural Press, 1948.

Le Corbusier, New World of Space, New York: Reynal and Hitchcock, 1948.

Le Corbusier, The Modulor, London: Faber and Faber, 1954. 
Le Corbusier, Creation is a Patient Search, New York: Praeger, 1960.

Le Corbusier, Le Corbusier Talks with Students form the Schools of Architecture, New York: Orion Press, 1961.

Le Corbusier, Oeuvre Complète Vols 1-8, London: Thames \& Hudson, 1964.

Le Corbusier, The Radiant City: Elements of a Doctrine of Urbanism to be Used as the Basis of Our MachineAge Civilization, New York: Orion Press, 1967.

Le Corbusier, The Athens Charter, New York: Grossman, 1973.

Moholy-Nagy, Sibyl. “The Achievement of Le Corbusier,” Arts Magazine, 40, 1965, pp. 40-45.

Mumford, Lewis. “Yesterday's City of Tomorrow," Architectural Record, 132, 1962, pp. 139-144.

Mumford, Lewis. Highway and the City, New York: Harcourt, Brace and World, 1963.

Murray, Irena; Osley, Julian, eds. Le Corbusier and Britain: An Anthology, Abingdon: Routledge, 2009.

O’Byrne, Maria Cecilia. "El museo del Mundaneum : génesis de un prototipo, “ Massilia, 2004, pp.112-135.

Osborn, F.J. “Concerning Le Corbusier,” Town and Country Planning, 20, 1952, pp. 311-316.

Papadaki, Stamo, ed., Le Corbusier, Architect, Painter, Writer, New York: Macmillan, 1948.

Prakash, Vikramaditya. Chandigarh's Le Corbusier: The Struggle for Modernity in Postcolonial India, Seattle: University of Washington Press, 2002.

Passanti, Francesco. "The Vernacular, Modernism, and Le Corbusier," Journal of the Society of Architectural Historians, 56.4, 1997, pp. 438-451.

Raeburn, Michael; Wilson, Victoria eds. Le Corbusier: Architect of the Century, London: Arts Council of Great Britain, 1987.

Read, Herbert. "The City of To-morrow,” The Listener, No. 18, 1931, pp. 272-273.

Robertson, Howard and Yerbury, F.R. Examples of French Architecture, New York: Charles Scribner's Sons, 1928.

Rowe, Colin. "The Mathematics of the Ideal Villa," Architectural Review, Vol. 101, 1947, pp. 101-104.

Schnoor, Christoph. (ed.) Le Corbusier: La construction des villes , Zurich, Verlag, 2008.

Sekler, Eduard; Curtis, William. Le Corbusier at Work: The Genesis of the Carpenter Center for the Visual Arts MIT Press: Cambridge, Mass., 1978.

Sekler, Mary P. M. The Early Drawings of Charles-Eduard Jeanneret (Le Corbusier), New York: Garland Publishing, 1977.

Sherer, Daniel. "Le Corbusier's Discovery of Palladio in 1922 and the Modernist Transformation of the Classical Code," Perspecta, Vol. 35, 2004, pp. 20-39.

Silver, Kenneth E. Espirit de Corps: The Art of the Parisian Avant-garde and the First World War, 1914-1925, Princeton: Princeton University Press, 1989.

Stirling, James. "Garches and Jaoul: Le Corbusier as Domestic Architect in 1927 and 1953," Architectural Review Vol. 118, 1955, pp. 145-151.

Stirling, James. "Ronchamp and the Crisis of Rationalism," Architectural Review, March, 1956, pp. $155-61$.

Stirling, James. “"The Functional Tradition’ and Expression,” Perspecta, 6, 1960, pp. 88-97.

Summerson, John. Heavenly Mansions and Other Essays on Architecture, London: Cresset Press, 1949.

Takhar, Jaspreet. ed., Celebrating Chandigarh, Chandigarh: Chandigarh Perspective, 2001. 
Taylor, Brian Brace. Le Corbusier: La Cité de Refuge 1929/33, Paris: Equerre, 1980.

Tomlinson, Harold. “Towards a New Architecture,” Architects’ Journal, No.127, 1927, pp. 378-379.

Turner, Paul. The Education of Le Corbusier, New York: Garland Publishing, 1977.

Vogt, Adolf Max. Le Corbusier, The Noble Savage: Towards an Archeology of Modernism, Cambridge, Mass.: MIT Press, 2000.

Walden, Russell. (ed), The Open Hand: Essays on Le Corbusier, MIT Press: Cambridge, Mass., 1977

The authors would like to acknowledge the thoughtful suggestions provided by Mary McLeod, and the support of the staff of the Canadian Centre for Architecture in Montreal during a visit in November 2014. 